\title{
Chemical immersion coatings to improve biological degradability of magnesium substrates for potential orthopaedic applications
}

\author{
Sridevi Brundavanam, Gérrard Eddy Jai Poinern, Derek Fawcett \\ Murdoch Applied Nanotechnology Research Group, Department of Physics, Energy Studies and Nanotechnology, School of Engineering and \\ Energy, Murdoch University, Murdoch, Western Australia 6150, Australia
}

Email address:

g.poinern@murdoch.edu.au (G. E. J. Poinern)

\section{To cite this article:}

Sridevi Brundavanam, Gérrard Eddy Jai Poinern, Derek Fawcett. Chemical Immersion Coatings to Improve Biological Degradability of Magnesium Substrates for Potential Orthopaedic Applications. International Journal of Biomedical Materials Research.

Vol. 2, No. 2, 2014, pp. 7-14. doi: 10.11648/j.ijbmr.20140202.11

\begin{abstract}
Historically, cobalt-chromium, stainless steel and titanium alloys have been the main principal materials used in a variety of medical procedures for load-bearing implants in the body. Magnesium and magnesium-based alloys have the potential to be used as short-term structural support during the healing process of damaged hard tissues and diseased bone. Unlike traditional biologically compatible metals, which are not biologically degradable, magnesium based alloys offer both biological degradability and biological absorbability. Despite the many advantages offered by magnesium, its rapid degradation rate in the highly aggressive and corrosive body fluid environment has severely limited its present day medical application. This article reviews the chemical immersion technique for producing calcium phosphate coatings on magnesium substrates for slowing down the degradation rate while maintaining the biological compatibility and absorbability.
\end{abstract}

Keywords: Magnesium, Biodegradability, Chemical Immersion, Bone Tissue Engineering

\section{Introduction}

Biologically compatible materials have been engineered into a variety of medical devices and implants to assist in healing, replace diseased tissues and in some drastic cases completely replace damaged tissues. The repair and replacement of diseased or damaged hard tissues presents a major challenge to patient health, wellbeing and quality of life. A major consequence of tissue damage or loss resulting from accidents or diseases is the psychological impact on patient wellbeing. For example, even minor injuries to fingers or toes that interfere with function and usually heal without much trouble can have a significant impact. While severe bone diseases and injuries that result in the loss of a limb creates functional problems for patients for many years. In many cases the device or implant is temporary and only needs to remain in the body during the healing process. Once the healing process is complete, a second surgical procedure is required to remove the device or implant which significantly increases patient site morbidity and associated health costs [1-3]. Alternatively, when an implant needs to remain in the body permanently, as in the case of a total joint replacement, long-term biocompatibility, mechanical strength and structural stability become important factors that must be addressed.

Biologically compatible polymers have been extensively investigated since the 1950's for a variety of potential tissue engineering applications. Natural polymers such as collagen $[4,5]$, chitosan $[6,7]$, hyaluronic based derivatives $[8,9]$, polysaccharides $[10,11]$, and a variety of protein based materials such as fibrin gel[12, 13] have all been extensively studied and found to be suitable for a wide range of tissue engineering applications. Synthetically manufactured biologically degradable and biologically absorbable polymers such as Poly (lactic acid), PLA [14, 15], Poly (L-lactic acid), PLLA [16, 17], Poly (lactic-co-glycolic acid), PLGA [18, 19], Poly-caprolactone PCL [20, 21] and Poly (glycolic acid) PGA $[22,23]$ have all being investigated and used in a variety of biomedical applications. For example, biodegradable sutures currently in clinical use are made from PLA and PGA. These have also been extensively investigated for the controlled delivery of drugs to specific organs within the body [24-26]. Advantages of using biological compatible polymers arise from their low toxicity within the body and the ability to 
control their degradation rate. Furthermore, the by-products of degradation can be easily handled by the body's natural processes and excreted in the urine [27]. Polymers can also be produced in a variety of shapes and structures such as disks, films, fibres and pellets to meet the specific requirements for a particular application. In addition, polymers can be produced with micrometre and nanometre scale typographical surface features to enhance cell-substrate interactions with the surface of the implant [28].

Unfortunately, polymers with all their many advantages are limited by their low mechanical strength, which severely restricts their use in load bearing and hard tissue supporting applications. Metals have more desirable mechanical properties due to their relatively high strength, elastic modulus fracture toughness and resilience and as a result several metallic biomaterials such as cobalt-chromium-based steel alloys, titanium-based alloys, nickel-based alloys and stainless steels have been widely used as implant materials [29-31]. However, studies have shown that conventional surgical metal alloys are not biologically absorbable and because of corrosion and wear, there is a release toxic metallic ions into surrounding cells and tissues [32-34]. These detrimental metallic ions induce an unfavourable inflammatory response from the body's immune system and the surrounding tissues, which significantly reduces the biocompatibility of the implant [33]. Furthermore, the significant difference in mechanical properties between metal implants and surrounding bone tissue results in a clinical phenomenon known as stress shielding. For example, the elastic modulus of both cobalt-chrome alloys and stainless steel is approximately ten times larger than that of bone, while a titanium alloy such as Ti-6Al-4V is around five times greater [35]. Normally, bone tissues are constantly undergoing remodelling and modification in response to the stresses produced during everyday activities. However, the presence of a metal implant creates stress-shielding, which results in a major portion of the load been carried by the implant. Thus, with most of the load been carried by the implant, the surrounding bone tissues experience significantly less load related stress and as a result leads to bone resorption, mechanical instability and the ultimate failure of the implant [36]. In addition, metallic implants used as temporary structural supports, such as pins, screws, and plates often need to be removed by a second surgical procedure once the healing process has taken place. The increased health costs and morbidity associated with the second surgical procedure highlights the need for new biologically compatible materials that can provide short-term structural support during the healing process. Then after healing has taken place to an acceptable level, the material would then biologically degrade and safely be reabsorbed and metabolized by the body.

One interesting alternative to conventional metals used as current bio-implants is magnesium. Magnesium $(\mathrm{Mg})$ is a lightweight, silvery-white metal that has been extensively used in alloy form in a wide range of engineering applications such as aerospace and automotive [37]. The density of $\mathrm{Mg}$ and its alloys are around $1.74 \mathrm{~g} / \mathrm{cm}^{3}$ at $20^{\circ} \mathrm{C}$, which is 1.6 and 4.5 times less dense than aluminium and steel, respectively. Interestingly, the density of pure $\mathrm{Mg}$ is $1.74 \mathrm{~g} / \mathrm{cm}^{3}$, while natural bone ranges from around 1.8 to $2.1 \mathrm{~g} / \mathrm{cm}^{3}$ and the elastic modulus of $\mathrm{Mg}$ and human bone are $45 \mathrm{GPa}$ and 40 to $57 \mathrm{GPa}$ respectively [38, 39]. It is because of the close similarity in the respective densities and elastic moduli that have made $\mathrm{Mg}$ a promising candidate for hard tissue engineering applications. The mechanical properties of $\mathrm{Mg}$ being similar to natural bone means that it has the potential to significantly reduce the possibility of stress shielding and prevent the associated bone resorption problems. $\mathrm{Mg}$ is also biologically degradable and biologically absorbable, with both $\mathrm{Mg}$ and its corrosions products considered physiologically beneficial, with as much as $30 \mathrm{~g}$ stored in the bone tissues and muscles of an adult body [40]. The body uses $\mathrm{Mg}$, a bivalent ion, in a number of metabolic processes and to form apatite in the bone matrix [41]. And recent studies by Robinson et al. have shown that $\mathrm{Mg}$ has novel antibacterial properties against pathogens such as Escherichia coli, Pseudomonas aeruginosa and Staphylococcus aureus [42]. Because of these advantageous properties $\mathrm{Mg}$ has gained significant interest as a potential biologically degradable material that removes the need for additional surgeries to reclaim pins, screws, and plates used in the short term while the healing process takes place. Figure 1 presents an ideal life span of an $\mathrm{Mg}$ implant that slowly degrades and allows regenerating bone tissues to progressively carry the load. The use of $\mathrm{Mg}$ as an implant material also has the potential to avoid the long-term complications associated with conventional metal implants in the body.

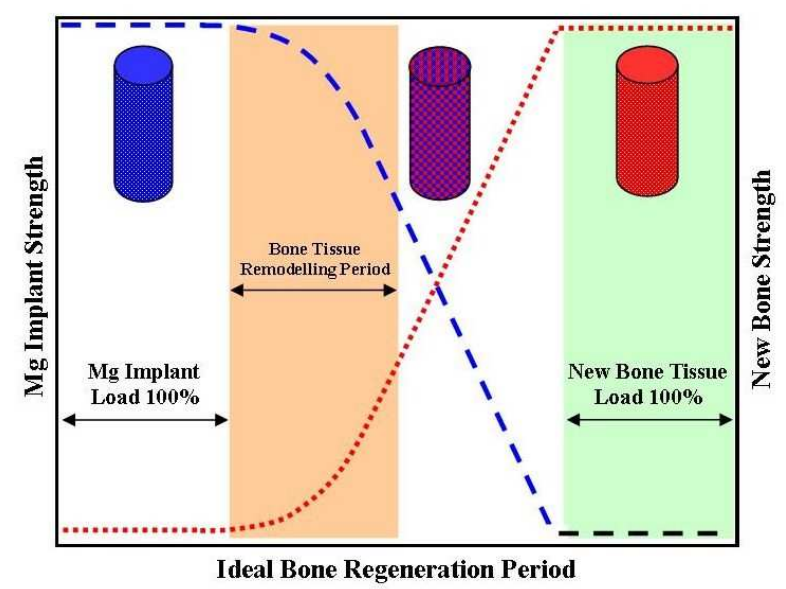

Figure 1. Graphical representation of an ideal load carrying transition between a slowly degrading $\mathrm{Mg}$ implant and progressively regenerating bone tissue

\section{Biological Degradation of Magnesium}

The main limitation that prevents $\mathrm{Mg}$ being used in orthopaedic applications is its low corrosion resistance in body fluids, which are composed of water, dissolved oxygen, proteins and electrolytic ions such as chloride and hydroxide. In this highly corrosive aqueous environment results in the rapid release of ions from the metal surface which combine 
with ions in the fluid to form chemical species, such as metal oxides, hydroxides, chlorides and other compounds [43]. Generally metals have a tendency to corrode in electrolytic environments with some metals having a greater propensity to degrade more rapidly than others as seen in Table 1. However, the interfacial region has also a significant bearing on the overall performance of metallic bio-implants. This can be shown in table The formation of metal oxides results in the creation of an oxide layer composed of $\mathrm{Mg}(\mathrm{OH})_{2}$ that adheres to the metal surface. The oxide layer is slightly soluble and reacts with chorine ions to form highly soluble magnesium chloride and the rapid production of hydrogen gas bubbles [44, 45]. The localised formation of gas bubbles generally begins just after surgery and continues for periods as long as three weeks. During this post surgery period, the $\mathrm{pH}$ around the implant increases and results in alkalization of the surrounding tissue environment. The presence of hydrogen bubbles and local alkalization can severely affect $\mathrm{pH}$ dependent physiological processes in the vicinity of the implant and delay tissue healing [46]. However, the use of a subcutaneous needle can be used to prevent significant build up of gas around the implant. Furthermore, in his study Song has suggested that small hydrogen evolution rates of around 0.01 $\mathrm{ml} / \mathrm{cm}^{2} /$ day can be easily handled by the human body and does not constitute a serious threat [47]. The high initial corrosion rate produces a thick oxide layer, which fully covers and seals the metal surface to form a passive layer, which physically stops or severely limits the migration of ionic species and hydrogen gas across the metal oxide solution interface. Unfortunately, the high corrosion rate during the first two to three weeks can cause a significant reduction in the mechanical and structural integrity of the implant before the bone tissues have had sufficient time to fully heal.

Table 1. Electrochemical series of selected metallic ions and their voltage potential [78]

\begin{tabular}{ll}
\hline Metal ions & Potential (Volts) \\
\hline $\mathrm{Au}^{3+}$ & +1.420 \\
$\mathrm{Pt}^{2+}$ & +1.200 \\
$\mathrm{Cu}^{2+}$ & 0.345 \\
$\mathrm{Cd}^{2+}$ & -0.402 \\
$\mathrm{Fe}^{2+}$ & -0.440 \\
$\mathrm{Cr}^{2+}$ & -0.710 \\
$\mathrm{Zn}^{2+}$ & -0.762 \\
$\mathrm{Al}^{3+}$ & -1.670 \\
$\mathrm{Mg}^{2+}$ & -2.340 \\
\hline
\end{tabular}

In atmospheric air at room temperature $\mathrm{Mg}$ corrodes to form a thin grey oxide layer over its surface. The oxide layer then reacts with atmospheric moisture to form a more stable magnesium hydroxide $\left[\mathrm{Mg}\left(\mathrm{OH}_{2}\right)\right]$ and hydrogen gas [43].Under standard environmental conditions, the $\mathrm{Mg}\left(\mathrm{OH}_{2}\right)$ layer is able to provide some degree of protection and is also capable of slowing down the corrosion rate even under aqueous conditions [48]. When $\mathrm{Mg}$ is exposed to an aqueous environment the corrosion process can be expressed by the following equations. The primary anodic reaction involves metallic $\mathrm{Mg}$ being converted to $\mathrm{Mg}^{2+}$ ions as seen in equation (1), meanwhile the reaction occurring at the cathode, presented in equation 2, involves the reduction of protons.

Anodic reaction:

$$
\mathrm{Mg} \rightarrow \mathrm{Mg}^{2-}+2 \mathrm{e}^{-}
$$

Cathodic reaction:

$$
2 \mathrm{H}_{2} \mathrm{O}+2 \mathrm{e}^{-} \rightarrow 2 \mathrm{OH}^{-}+\mathrm{H}_{2}
$$

The general reaction of the overall corrosion process is represented by equation (3) below.

$$
\mathrm{Mg}_{(\mathrm{s})}+2 \mathrm{H}_{2} \mathrm{O}_{(\mathrm{l})} \rightarrow \mathrm{Mg}(\mathrm{OH})_{2(\mathrm{~s})}+\mathrm{H}_{2(\mathrm{~g})}
$$

However, when $\mathrm{Mg}$ is exposed to chloride ions present in the physiological environment, the $\mathrm{Mg}(\mathrm{OH})_{2}$ interfacial layer reacts with the chloride ions to form highly soluble $\mathrm{MgCl}_{2}$. The high solubility of $\mathrm{MgCl}_{2}$ and the significant reduction in corrosion resistance provided by the reacting $\mathrm{Mg}(\mathrm{OH})_{2}$ layer results in rapid dissolution of the underlying $\mathrm{Mg}$ substrate and the formation of hydroxide ions and hydrogen gas [49]. The resulting dissolution and corrosion rate are import factors in the use of $\mathrm{Mg}$ as a biomaterial, since corrosion is likely to result in mechanical failure of an implant. Therefore, the corrosion rate must be taken into account when considering $\mathrm{Mg}$ and $\mathrm{Mg}$ based materials for hard tissue engineering and surgical applications. Ideally, the corrosion rate should be at a rate that allows temporary support of tissues during the recovery period. During the recovery period, initial mechanical strength would be maintained until the effects of corrosion start to occur. This would be followed by a gradual decrease in strength over the period of tissue recovery and finally the implant would be absorbed leaving the recovered tissues to carry the full load [50]. Other corrosion related factors that need to be considered is the increase in local $\mathrm{pH}$ and hydrogen evolution, both of which could have significant effects on tissues surrounding the implant. If $\mathrm{Mg}$ and $\mathrm{Mg}$ based materials are to be successfully used as an orthopaedic biomaterial, then the degradation behaviour and related factors of these materials need to be effectively controlled.

\section{Controlled Degradation Via Chemical Immersion Treatment}

In spite of magnesium's many advantageous material properties, its high chemical reactivity and poor corrosion resistance has prevented its widespread use in orthopaedic applications. In general, materials used in orthopaedic application such as titanium alloys will only experience load induced stresses in the inner core of the implant, while its surface will be exposed and interact with the surrounding physiological environment. Because the interfacial properties between the implant surface and the physiological environment are very important, different processing techniques such as alloying, thermal spray coating, ion implantation, micro-arc oxidation, anodizing and surface coating treatments have been widely used to improve the biocompatibility of the underlying material $[43,51,52]$. In the 
case of $\mathrm{Mg}$, the processing techniques have primarily focused on improving the corrosion resistance of the metal when exposed to the biological environment $[53,54]$.

Bioactive coatings such as calcium phosphate materials have been successfully applied to a variety of metallic implants in order to improve biocompatibility, promote attachment to surrounding hard tissues and to suppress the release of corrosion products into the human body [31]. Calcium phosphate $(\mathrm{CaP})$ coating can be applied to a variety of substrate materials of varying sizes and shapes using a relatively straight forward technique known as chemical immersion [55, 56]. Apart from convincing experimental results of a number of independent studies that indicate $\mathrm{CaP}$ coatings can significantly improve corrosion resistance [57-59], the coatings also have the advantages of being non-toxic, display good biocompatibility and have enhanced bioactivity properties with respect to bone cells and other body tissues [60]. Despite these many advantages, a number of studies have also shown a number of shortcomings such as poor coating adherence, surface cracking and effective control of the CaP phases formed during immersion [54]. Regardless of these shortcomings, biologically mimicking CaP coating formed via the chemical immersion technique have the potential to control the corrosion rate and enhance the biocompatibility of $\mathrm{Mg}$ and $\mathrm{Mg}$ based alloys for orthopaedic applications.

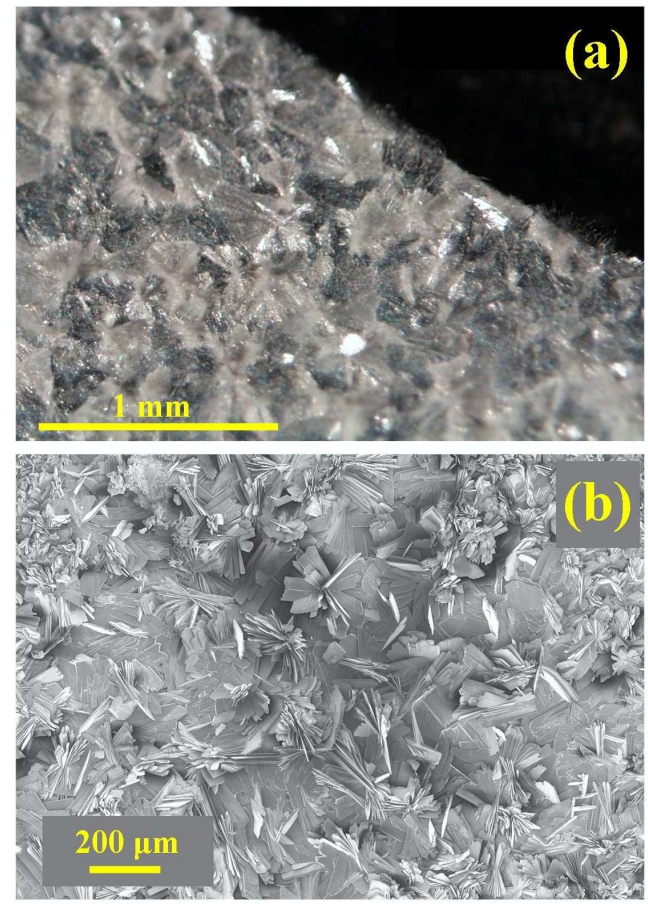

Figure 2. Magnesium substrate coated with a DCPD coating: (a) Optical microscopy image of surface coating and (b) Higher resolution field emission scanning electron microscopy micrograph showing plate-like surface structures present in the coating.

The results of a number of recent studies have confirmed that $\mathrm{CaP}$ coatings were able to enhance the corrosion resistance and improve the biocompatibility of $\mathrm{Mg}$ and $\mathrm{Mg}$ based alloys [61-63]. For example, a study by Xu et al. using a chemical immersion based technique was able to form a brushite $\left(\mathrm{CaHPO}_{4} \cdot 2 \mathrm{H}_{2} \mathrm{O}\right)$ surface coating on an $\mathrm{Mg}-\mathrm{Mn}-\mathrm{Zn}$ alloy substrate using an alkaline electrolyte. Regrettably, subsequent testing revealed that the coating was porous and failed to prevent corrosion of the substrate in a simulated body fluid. Nonetheless, the coating did significantly reduce the corrosion rate and provide some degree of protection against the simulated body fluid [64]. The study not only found improved corrosion resistance, but also found that the brushite layer improved biocompatibility, promoted bone formation and subsequently transformed into hydroxyapatite $\left[\mathrm{Ca}_{10}(\mathrm{OH})_{2}\right.$ $\left(\mathrm{PO}_{4}\right)_{6}$ ] (HAP) with time [65]. In another study, Wang et al. was able to produce a calcium-phosphate coating by immersing an $\mathrm{Mg}$ substrate into a solution containing $\mathrm{Ca}$ and $\mathrm{P}$ [Ca $\left(\mathrm{NO}_{3}\right)_{2}$ and $\mathrm{Na}_{2} \mathrm{HPO}_{4}$ ] to form a di-calcium phosphate di-hydrate (DCPD) surface coating [56]. The surface coating of DCPD was effective in improving the corrosion resistance of the substrate for the first 21 days of immersion in a simulated body fluid. Figure 2 and the enlarged micrograph shown in Figure 3 reveal structures in a typical DCPD coating formed by a chemical immersion technique developed by the authors. In a novel chemical immersion technique, Yanovska et al. incorporated low magnetic fields into a one-step immersion method. During this process the Mg substrate was immersed into an aqueous electrolyte containing $\mathrm{Ca}\left(\mathrm{NO}_{3}\right)_{2} \cdot 4 \mathrm{H}_{2} \mathrm{O}$ and $\mathrm{Na}_{2} \mathrm{HPO}_{4} \cdot 12 \mathrm{H}_{2} \mathrm{O}$. The influence of magnetic fields in orientating the crystals during the coating formation was investigated, along with the types of phases present. The technique produced coatings composed of DCPD and HAP phases, the coatings were found to enhance corrosion resistance and significantly reduced the degradation rate of the substrate [66]. For example, Figure 4 presents a set of representative potential-dynamic polarization curves showing the improvement in corrosion resistance of an $\mathrm{Mg}$ substrate after receiving a DCPD coating. The corrosion testing was carried out in a phosphate buffer saline (PBS) solution at $37{ }^{\circ} \mathrm{C}$ as a first step in assessing the coating bioactivity.

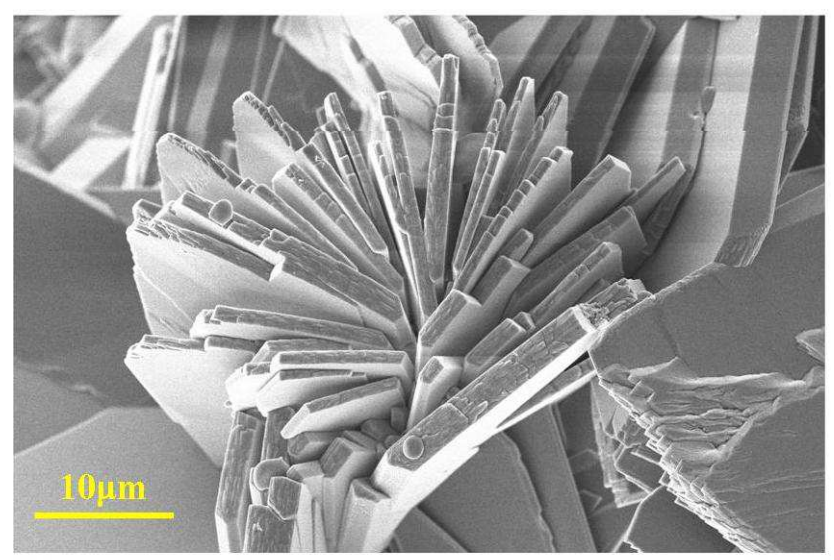

Figure 3. Enlarged field emission scanning electron microscopy micrograph showing the DCPD flower-like plate structures present in the coating.

The use of HAP coatings has a number of advantages besides improving the corrosion resistance of $\mathrm{Mg}$ and $\mathrm{Mg}$ 
based alloys in the physiological environment. HAP is a major inorganic component found in natural bone tissues, therefore using HAP as a biological coating on $\mathrm{Mg}$ offers a number of attractive properties such as its good biocompatibility and bioactivity properties with respect to bone cells and other body tissues [67]. Other desirable properties include slow biodegradability in situ and its ability to promote osteoconductivity and osteoinductivity, which can accelerate the in-growth of surrounding tissues [68-70]. These properties are of particular importance in the case of bone tissue that are constantly being replaced and removed by bone cells such as osteoblasts and osteoclasts, via a process known as remodelling. Studies have also shown that HAP displays an excellent biocompatible response to soft tissue such as skin, muscle and gums [71]. However, due to its low mechanical strength HAP is restricted to low load bearing clinical applications. Typical examples include coating the surface of conventional metallic implants to improve their biocompatibility and bioactivity, bone augmentation, drug delivery, and as filler material for both bone and dental implants [72-76].

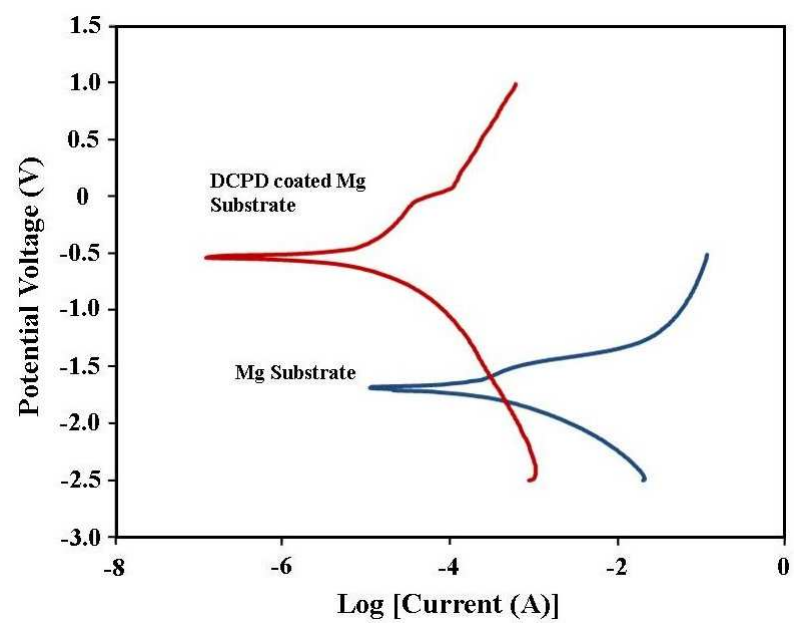

Figure 4. Polarization curves showing the improvement in corrosion resistance of an $\mathrm{Mg}$ substrate after receiving a DCPD coating. The testing solution used was a phosphate buffer saline solution at $37^{\circ} \mathrm{C}$ and a pH of 7.4

HAP coatings can be directly deposited directly onto $\mathrm{Mg}$ substrates using chemical immersion techniques or by chemically converting modifying a pre-existing calcium phosphate coating. For example Tomozawa et al. have treated pure magnesium substrates with Calcium-EDTA and $\mathrm{KH}_{2} \mathrm{PO}_{4}$ based solutions [77]. The solution concentrations were varied from $0.01 \mathrm{M} / \mathrm{L}$ to $0.25 \mathrm{M} / \mathrm{L}$, while the treatment temperatures were varied from $313 \mathrm{~K}$ to $373 \mathrm{~K}$. Optimisation of their immersion process revealed that by adjusting the concentration and thermal treatment time to $0.25 \mathrm{M} / \mathrm{L}$ and $2 \mathrm{~h}$, respectively, dense rod-like HAP crystals grew along the c-axis. HAP formation produced a dense, crystalline and uniform coating without the formation of a $\mathrm{Mg}(\mathrm{OH})_{2}$ intermediate layer. The HAP coating formed by this chemical immersion technique was found to be stable and capable of significantly improving the corrosion resistance of the $\mathrm{Mg}$ substrates. Alternatively, a two-step immersion technique can be adopted to synthesize HAP coating on an Mg substrate. During the first step a CaP coating is deposited onto the substrate. Then during the second step the process converts the calcium phosphate into HAP. For example, the authors have produced a dicalcium phosphate dehydrate (brushite DCPD) coating on $\mathrm{Mg}$ substrates from aqueous solutions containing $\mathrm{Ca}\left(\mathrm{NO}_{3}\right)_{2}$ and $\mathrm{KH}_{2} \mathrm{PO}_{4}$ at $298 \mathrm{~K}$. During the second step DCPD coated substrates are immersed into a solution of sodium hydroxide $(\mathrm{NaOH})$ at $80^{\circ} \mathrm{C}$ for $2 \mathrm{~h}$. At the end of this low temperature thermal treatment the DCPD is converted to HAP. The authors are currently carrying out degradation studies to determine the corrosion resistance of DCPD and DCPD converted to HAP coatings, Figure 4. Preliminary results indicate that significant improvement in corrosion resistance can be achieved by applying CaP coatings to $\mathrm{Mg}$ substrates. The chemical immersion technique is a straightforward and economic technique for synthesizing $\mathrm{CaP}$ coatings such as HAP on magnesium substrates. The coatings produced by chemical immersion were capable of slowing down the degradation rate by significantly improving corrosion resistance of the coated substrate.

\section{Conclusion}

In recent years, there has been significant research into developing novel biologically absorbable materials for orthopaedic applications. $\mathrm{Mg}$ has demonstrated that it has some attractive properties and the potential to be used as a biologically degradable implant material. $\mathrm{Mg}$ is an extremely biocompatible material with mechanical properties similar to bone tissue. However, in spite of having good biocompatibility and bioactivity properties, $\mathrm{Mg}$ 's poor corrosion resistance to the physiological environment has prevented its successful use in orthopaedic applications. Chemical immersion is an economic, efficient and straightforward technique that offers a direct method of depositing CaP coatings such as DCPD and HAP on $\mathrm{Mg}$ substrates. Not only do CaP coatings have the potential to reduce the corrosive effects of the physiological environment, but they also offer the potential to significantly improve biocompatibility and promote bone formation at the surface of an $\mathrm{Mg}$ based implant. Coating $\mathrm{Mg}$ with a dense $\mathrm{CaP}$ layer that significantly reduces the corrosion rate makes this an attractive material for the manufacture of biodegradable orthopaedic implants. While a significant amount of research has been conducted in recent years investigating the potential medical use of $\mathrm{Mg}$ and commercially available $\mathrm{Mg}$ alloys, further research is needed to fully evaluate methods of reducing the degradation rate in the physiological environment. Chemical immersion is one method that has the potential to deliver $\mathrm{CaP}$ coated $\mathrm{Mg}$ based materials with the potential to be used in the manufacture of biodegradable implants. However, further research is needed to fully optimize the operational parameters of the chemical immersion technique so that there is greater control of the resulting coating properties. In addition, further in vitro and in vivo studies are needed to verify the mechanical integrity of 
the coatings and their biological compatibility with bone tissues.

\section{Acknowledgements}

The authors would like to thank Mr Gordon Thomson for his assistance with the optical microscopy work and Associate Professor Gamini Senanayake for his assistance with the electrochemical experiments in this work.

\section{References}

[1] Lars L. The Bone and Joint Decade 2000-2010, Bull World Health Organ [online], 2003; 81: 629-629.

[2] Park JB and Kim YK, Metallic Biomaterials, Biomaterials: Principles and Applications, ed. Park JB and Bronzino JD, (Boca Raton: CRC Press, 2003), 1-20.

[3] Labek G, Thaler M, Janda W, Agreiter M, and Stockl B. Revision rates after total joint replacement: Cumulative results from worldwide joint register datasets. Journal of Bone \& Joint Surgery, 2011; 93(B3): 293-297.

[4] Chun TH, Hotary KB, Sabeh F, Saltiel AR, Allen ED, Weiss SJ, A Pericellular Collagenase Directs the 3-Dimensional Development of White Adipose Tissue, Cell, 2006; 125(3): 577-591.

[5] Dai NT, Williamson MR, Khammo N, Adams EF, Coombes AGA, Composite cell support membranes based on colla gen and polycaprolactone for tissue engineering of skin, Biomaterials, 2004; 25: 4263-4271.

[6] Wang X, Du Y, Luo J, Lin B, Kennedy JF, Chitosan/organic rectorite nanocomposite films: Structure, characteristic and drug delivery behavior, Carbohydrate Polymers, 2007; 69: $41-49$.

[7] Dang JM, Leong KW, Natural polymers for gene delivery and tissue engineering, Advanced Drug Delivery Reviews, 2006; 58: $487-499$.

[8] Halbleib M, Thomas S, Claudio de L, von Heimburgc D, Hauner $\mathrm{H}$, Tissue engineering of white adipose tissue using hyaluronic acid-based scaffolds. I: in vitro differentia tion of human adipocyte precursor cells on scaffolds, Bio materials, 2003; 24: 3125-3132.

[9] Kafedjiiski K, Jetti RKR, Florian F, Hoyer H, Werle M, Hoffer $\mathrm{M}$, Bernkop-Schnurch A, Synthesis and in vitro evaluation of thiolated hyaluronic acid for mucoadhesive drug delivery, International Journal of Pharmaceutics, 2007; 343(1-2): p.48-58.

[10] Yang L, Li-Ming Z, Chemical structural and chain confor mational characterization of some bioactive polysaccharides isolated from natural sources, Carbohydrate polymers, 2009; 76(3): 349-361.

[11] Kanazawa A, Suzuki M, Solid-state poly-condensation of natural aldopentoses and 6- deoxyaldohexoses. Facile preparation of highly branched polysaccharide, Polymer, 2006; 47(1): 176-183.

[12] Jockenhoevel S, Zund G, Hoerstrup SP, Chalabi K, Sachweh JS, Demircan L, Messmer BJ, Turina M, Fibrin gel - ad vantages of a new scaffold in cardiovascular tissue engi neering, European Journal of Cardio-thoracic Surgery, 2011;.19: 424-430.

[13] Ryan EA, Mockros LF, Stern AM, Lorand L, Influence of a Natural and a Synthetic Inhibitor of Factor XIIIa on Fibrin Clot Rheology, Biophysical Journal, 1999; 77: 2827-2836.

[14] Kanczler JM, Ginty PJ, Barry JJA, Clarke NMP, Howdle SM, Shakesheff KM, Oreffo ROC, The effect of mesenchymal populations and vascular endothelial growth factor delivered from biodegradable polymer scaffolds on bone formation. Biomaterials. 2008; 29: 1892-1900.

[15] Rimondini L, Nicoli-Aldini N, Fini M, Guzzardella G, Tschon M, Giardino R, In vivo experimental study on bone regeneration in critical bone defects using an injectable bio degradable PLA/PGA copolymer. Oral Surg. Oral Med. Oral Pathol. Oral Radiol. Endod. 2005; 99: 148-54.

[16] Wang Z, Wang S, Marois Y, Guidoin R, Zhang Z, Evaluation of biodegradable synthetic scaffold coated on arterial pros theses implanted in rat subcutaneous tissue. Biomaterials, 2005; 26: 7387-7401

[17] Sato T, Chen G, Ushida T, Ishii T, Ochiai N, Tateishi T, Ta naka J, Evaluation of PLLA-collagen hybrid sponge as a scaffold for cartilage tissue engineering. J. M Sec. 2004; C24: 365-372.

[18] Qiao M, Chen D, Ma X, Liu Y, Inject-able biodegradable temperature-responsive PLGA-PEG-PLGA copolymers: Synthesis and effect of copolymer composition on the drug release from the copolymer-based hydrogels. Int. J. Pharm. 2005; 294: 103-112.

[19] Lee JJ, Lee SG, Park JC, Yang YI, Kim JK, Investigation on biodegradable PLGA scaffold with various pore size structure for skin tissue engineering. J. Current. App. Phys. 2007; 7S1: e37-e40.

[20] Todo M, Park SD, Takayama T, Arakawa K, Fracture mi cro-mechanisms of bio-absorbable PLLA/PCL polymer blends. J. Eng. Frac. Mech, 2007; 4: 1872-1883.

[21] Rezgui F, Swistek M, Hiver JM, G'Sell C, Sadoun T, De formation and damage upon stretching of degradable poly mers (PLA and PCL). J. Polymer, 2005; 46: 7370-7385.

[22] Wang YC, Lin MC, Wang DM, Hsieh HJ, Fabrication of a novel porous PGA-chitosan hybrid matrix for tissue engi neering. Biomaterials, 2003; 24: 1047-1057.

[23] Hsieh CY, Tsai SP, Wang DM, Chang YN, Hsieh HJ, Prepa ration of g-PGA/chitosan composite tissue engineering ma trices. Biomaterials, 2005; 26: 5617-5623.

[24] Kreuter J: Nanoparticulate systems for brain delivery of drugs. Adv. Drug Del. Rev. 2001; 47: 65-81.

[25] Han ML, Lowman AM, Biodegradable nanoparticles for drug delivery and targeting. Current Opinions Solid State Mat. 2002; 6: 319-327.

[26] Blaker JJ, Knowles JC, Day RM, Novel fabrication tech niques to produce microspheres by thermally induced phase separation for tissue engineering and drug delivery. Acta Biomaterialia.2008; 4: 264-272.

[27] Lyu SP, Untereker D, Degradability of polymers for im plantable biomedical devices. Int. J Mol Sci Sep, 2009; 10(9): 4033-4065. 
[28] Le X, Poinern GEJ, Ali N, Berry CM and Fawcett D, Engi neering a biocompatible scaffold with either micrometre or nanometre scale surface topography for promoting protein adsorption and cellular response. International Journal of Biomaterials 2013; Article ID 782549:16 pages.

[29] Long $M$ and Rack HJ, Titanium alloys in total joint re placement - a materials science perspective. Biomaterials, 1998; 19: 1621-1639.

[30] Dearnly PA, A brief review of test methodologies for sur face-engineered biomedical implant alloys, Surface and Coatings Technology, 2005; 198(1-3): 483-490.

[31] Geetha M, Singh AK, Asokamani R, Gogia AK, Ti based biomaterials, the ultimate choice for orthopaedic implants - A review, Progress in Materials Science, 2009; 54: 397-425.

[32] Hallab N, Merritt K, Jacobs JJ, Metal Sensitivity in Patients with Orthopaedic Implants, J. Bone Joint Surg. Am., 2001; 83: 428-428.

[33] Lhotka C, Szekeres T, Steffan I, Zhuber K, Zweymuller K. Four-year study of cobalt and chromium blood levels in patients managed with two different metal-on-metal total hip replacements. Journal of Orthopedic Research, 2003; 21(2): 189-195.

[34] Haynes DR, Boyle SJ, Rogers SD, Howie DW, Vernon-Robert B, Variation in cytokines induced by patients from different prosthetic materials, Clinical Orthopaedics and Related Research, 1998; 352: 323-230.

[35] Li Y, Yang C, Zhao H, Qu S, Li X, Li Y, New developments of Ti-based alloys for biomedical applications. Materials, 2014; 7: $1709-1800$

[36] Nagels J, Stokdijk M, Rozing PM, Stress shielding and bone resorportion in shoulder arthroplasty, Journal of Shoulder and Elbow Surgery, 2003; 12(1): 35-39.

[37] Polmear IJ, Magnesium alloys and applications, Materials Science and Technology, 1994; 10(1): 1-16.

[38] Razavi M, Fathi MH, Meratian M et al. Microstructure, mechanical properties and biocorrosion evaluation of bio degradable AZ91-FA nanocomposites for biomedical appli cations, Materials Science and Engineering A, 2010; 527(26): 6938-6944.

[39] Feng A, Han Y, The microstructure, mechanical and corro sion properties of calcium phosphate reinforced ZK60A magnesium alloy composites, Journal of Alloys and Compounds, 2010; 504 : 585-593.

[40] Saris NL, Mervaala E, Karppanen H, Khawaja JA, Lewen stam A, Magnesium. An update on physiological, clinical and analytical aspects, Clinica Chimica Acta, 2009; 294: 1-26.

[41] Kim SR, Lee JH, Kim YT, Riu DH, Jung SJ, Lee YJ, Chung SC, Kim YH, Synthesis of Si, Mg substituted hydroxyap atites and their sintering behaviours, Biomaterials, 2003; 24(8): 1389-1398.

[42] Robinson AD, Griffith RW, Shechtman D, Evans RB, Con zemius MG, In vivo antibacterial properties of magnesium metal against Escherichia coli, Pseudomonas aeruginosa and Staphylococcus aureus, Acta Biomaterialia, 2010; 6: 1869- 1877.

[43] Poinern GEJ, Brundavanam S, Fawcett D, Biomedical Magnesium Alloys: A Review of Material Properties, Sur face
Modifications and Potential as a Biodegradable Ortho paedic Implant, American Journal of Biomedical Engineer ing 2012; 2(6): 218- 240.

[44] Shaw BA, Corrosion resistance of magnesium alloys. In: Ed: Stephens D. ASM handbook, Vol 13a: corrosion fundamen tals, testing and protection. UK: ASM Int.; 2003.

[45] Fekry AM, Ameerm MA, Electrochemistry and impedance studies on titanium and magnesium alloys in Ringer's solu tion, International Journal of Electrochemical Science, 2011; 6: 1342-1354.

[46] Witte F, Kaese V, Haferkamp H, Switzer E, Mey er-Lindenberg A, Wirth CJ, Windhagen $\mathrm{H}$, In vivo corro sion of magnesium alloys and the associated bone response, Biomaterials, 2005; 26(17): 3557-3563.

[47] Song G, Control of biodegradation of biocompatible magne sium alloys, Corrosion Science, 2007; 49(4): 1696-1701.

[48] Zeng RC, Zhang J, Huang WJ, Dietzel W, Kainer KU, Blawert $\mathrm{C}$, et al. Review of studies on corrosion of magne sium alloys. Transactions of Nonferrous Metals Society of China, 2006; 16(Supplement 2): s763-s771.

[49] Song G, Atrens A. Understanding Magnesium Corrosion: Framework for Improved Alloy Performance. Advanced Engineering Materials, 2003; 5(12): 837-858.

[50] Wang H, Shi ZM. In vitro biodegradation behaviour of magnesium and magnesium alloys. Journal of Biomedical Materials Research Part B: Applied Biomaterials, 2011; 98 B (2): 203-209.

[51] Roy R and Lee K. Biomedical application of diamond-like carbon coatings: A review. J Biomed Mater Res Part B Appl Biomater, 2007; 83: 72-84.

[52] Gray JE, Luan B, Protective coatings on magnesium and its alloys - a critical review, Journal of Alloys and Compounds, 2002; 336(1): 88-113.

[53] Wang J, Tang J, Zhang P, Li Y, Lai Y, Qin L. Surface modi fications of magnesium alloys developed for bioabsorbable orthopaedic implants: A general review. J Biomed Mater Res Part B Appl Biomater 2012; 100B: 1691-1701.

[54] Hornberger H, Virtanen S, Boccaccini A. Biomedical coat ings on magnesium alloys - A review. Acta Biomater 2012; 8: $2442-2455$.

[55] Cui FZ, Yang JX, Jiao YP, Lee IS, Yin QS, Zhang Y. Modi fication of degradation behaviour of magnesium alloy by IBAD coating of calcium phosphate. Surface \& Coatings Technology, 2008; 202(22-23): 5733-5736.

[56] Wang Y, Wei M, Gao J, Improve corrosion resistance of magnesium in simulated body fluid by dicalcium phosphate dihydrate coating, Materials Science and Engineering: C, 2009; 29: 1311-1316.

[57] Jo JH, Kang BG, Shin KS, et al. Hydroxyapatite coating on magnesium with $\operatorname{MgF}(2)$ interlayer for enhanced corrosion resistance and biocompatibility. J Mater Sci Mater. Med, 2011; 22: 2437-2447.

[58] Wang H, Guan S, Wang Y, et al. In vivo degradation behavior of $\mathrm{Ca}$-deficient hydroxyapatite coated $\mathrm{Mg}$-Zn-Ca alloy for bone implant application. Colloids Surf B. Biointerfaces, 2011; 88: 254-29. 
[59] Yang JX, Cui FZ, Lee I-S, et al. In vivo biocompatibility and degradation behavior of $\mathrm{Mg}$ alloy coated by calcium phos phate in a rabbit model. J. Biomater. Appl., 2012; 27: 153-164.

[60] Poinern GEJ, Brundavanam R, Le X, Nicholls PK, Cake MA, Fawcett D. The synthesis, characterisation and in vivo study of a bioceramic for potential tissue regeneration ap plications, Scientific Reports, 2014; 4, 6235: 1-9.

[61] Virtanen S, Keim S, Brunner JG, Fabry B. Control of mag nesium corrosion and biocompatibility with biomimetic coatings. Journal of Biomedical Materials Research Part B: Applied Biomaterials, 2011 96(1): 84-90.

[62] Yang JX, Cui FZ, Lee IS, et al. In vivo biocompatibility and degradation behaviour of $\mathrm{Mg}$ alloy coated by calcium phosphate in a rabbit model, Journal of Biomaterials Appli cations 2012; 27(2): 153-1643.

[63] Hiromoto S, Tomozawa M. Growth mechanism of hy droxyapatite-coatings formed on pure magnesium and corrosion behavior of the coated magnesium. Applied Sur face Science 2011; 257(19): 8253-8257.

[64] Xu L, Zhang E, Yang K, Phosphating treatment and corrosion properties of $\mathrm{Mg}-\mathrm{Mn}-\mathrm{Zn}$ alloy for biomedical application, Journal of Materials Science: Materials in Medicine, 2009; 20: 859-867.

[65] $\mathrm{Xu} \mathrm{L}$, Pan F, Yu G, et al. In vitro and in vivo evaluation of the surface bioactivity of a calcium phosphate coated mag nesium alloy, Biomaterials, 2009; 30: 1512-1523.

[66] Yanovska A, Kuznetsov V, Stanislavov A, Danilchenko S, Sukhodub L, Calcium phosphate coatings obtained biomimetically on magnesium substrates under low magnetic fields, Applied Surface Science, 2012; 258: 8577-8584.

[67] Poinern GJE, Brundavanam R, Le X, Djordjevic S, Prokic M, Fawcett $\mathrm{D}$, Thermal and ultrasonic influence in the formation of nanometer scale hydroxyapatite bio-ceramic. International Journal of Nanomedicine 2011:6 2083-2095.

[68] Blom A. Which scaffold for which application? Curr Ortho paed. 2007; 21(4): 280-287.
[69] Habibovic P, de Groot K. Osteoinductive biomaterials prop erties and relevance in bone repair. J Tissue Eng and Regen Med. 2007; 1(1): 25-32.

[70] Kalita SJ, Bhardwaj A, Bhatt HA. Nanocrystalline calcium phosphate ceramics in biomedical engineering. Materials Science and Engineering C. 2007; 27(3): 441-449.

[71] Taniguchi M, Takeyema H, Mizunna I, et al. The clinical application of intravenous catheter with percutaneous device made of sintered hydroxyapatite. Japanese J Artificial Organs. 1991; 20(2): 460-464.

[72] Hutmacher DW, Schantz JT, Lam CXF, Tan KC, Lim TC. State of the art and future directions of scaffold-based bone engineering from a biomaterials perspective. J. Tissue Eng Regen Med. 2007; 1: 245-260.

[73] Habraken WJ, Wolke JG, Jansen JA. Ceramic composites as matrices and scaffolds for drug delivery in tissue engineer ing. Adv Drug Deliver Rev. 2007; 59(4-5): 234-248.

[74] Silva RV, Camilli JA, Bertran JA, Moreira NH. The use of hydroxyapatite and autogenous cancellous bone grafts to repair bone defects in rats. Inter J Oral Maxillofacial Surg. 2005; 34(2): 178-184.

[75] Stoch A, Jastrzebski W, Dlugon E, et al. Sol-gel derived hydroxapatite coatings on titanium and its alloy Ti6 Al4V. J Mol. Struct. 2005; 744-747: 633-640.

[76] Vecchio KS, Zhang X, Massie JB, Wang M, Kim CW. Con version of bulk seashells to biocompatiable hydroxyapatite for bone implants. Acta Biomater. 2007; 3(6): 910-918.

[77] Tomozawa M, Sachiko Hiromoto S, Yoshitomo Harada Y, Microstructure of hydroxyapatite-coated magnesium pre pared in aqueous solution. Surface \& Coatings Technology 2010; 204: 3243-3247.

[78] Diamant RME, Applied Chemical Chemistry for Engineers, Pitman Publishing, 1972, Chap 5. 